\title{
NARCOTICS PREVENTION AMONG PRISONERS BY NATIONAL NARCOTICS AGENCY (BNN) $)^{\Omega}$
}

\author{
Hibnu Nugroho \\ Faculty of Law Universitas Jenderal Soedirman, Indonesia \\ E-mail: hibnunugroho@gmail.com
}

\begin{abstract}
Nowadays, Indonesia has high number of narcotics users. It includes narcotics abuse inside Correctional Institution. The research investigates whether law enforcement policy in narcotics eradication among prisoners has been effectively implemented or not and what impediments encountered by the National Narcotics Agency (BNN) in upholding law enforcement to fight against narcotics among prisoners. The research applied empirical juridical approach particularly analytical descriptive. The key informants in this research are Central Java BNN and Central Java Drugs Penitentiary. This research employed qualitative descriptive analysis while the content analysis applied legal interpretation, principles of law and legal theories. This belongs to Research and Development (R\&D) and the Theory of Law Enforcement Factors by Soerjono Soekanto. Narcotics prevention by National Narcotics Agency in prison is not effectively implemented due to lack of number of officials or guards to supervise the prisoners.
\end{abstract}

Keywords: prevention, narcotics, Correctional Institution

\begin{abstract}
Abstrak
Indonesia saat ini menjadi negara dengan pemakai narkotika yang sangat tinggi. termasuk penyalahgunaan narkotika yang terjadi di dalam lembaga pemasyarakatan. Penelitian ini membahas mengenai apakah kebijakan penegakan hukum dalam pemberantasan narkotika di kalangan narapidana sudah efektif dan kendala-kendala apa yang dihadapi BNN dalam melakukan penegakan hukum pemberantasan narkotika di kalangan narapidana. Penelitian dilakukan dengan menggunakan metode yuridis empiris dengan spesifikasi penelitian bersifat deskriptif analitis. Narasumber dalam penelitian ini adalah BNN Propinsi Jawa Tengah dan Lapas Narkoba Jawa Tengah. Analisis penelitian ini menggunakan diskriptif kualitatif dan analisis isi dengan menggunakan penafsiran hukum, asas asas hukum dan teori-teori hukum. penelitian ini mempergunakan metode analisis Penelitian dan Pengembangan (Research and Developmen/R\&D dan Teori Faktor-faktor penegakan Hukum dari Soerjono Soekanto. Penanggulangan pemakaian narkoba oleh BNN didalam Lapas masih belum maksimal karena muncul hambatan berupa kurangnya jumlah pegawai lapas untuk mengawasi warga binaan.
\end{abstract}

Kata Kunci: penanggulangan, narkotika, Lembaga Pemasyarakatan

Introduction

Circulation and additive substance-associated behavior becomes more obvious nowadays. It is a fact that drugs are around us. Based on joint survey between National Narcotics Agency and Health Research Center of Universitas Indonesia in 2008 , drug abuse in Indonesia show increasing trend and stay so. ${ }^{1}$
Drug consumption without medical indication nor doctor's prescription considered pathological (causing abnormality) even disrupt daily activities such home, school, campuss, and work environment. Drug addiction is caused by substances abuse and followed by substance tolerance (in higher dosages) and despair symptoms, which possess unbearable traits of desire, tend

$\Omega \quad$ This research was funded by Dana Hibah Fasilitasi Guru Besar Year 2016.

Paul Ricardo, “Upaya Penanggulangan Penyalahgunaan Narkoba Oleh Kepolisian (Studi Kasus Satuan Narkoba Metro Bekasi)", Jurnal Kriminologi Indonesia, Vol. 6 No.

III, December 2010, Jakarta: Departemen Kriminologi, Universitas Indonesia, page 232. 
to increase dosage, physical and physiological addiction. $^{2}$

United Nations (UN) Convention on the eradication of illegal traffic Narcotics and Psychotropic in 1988 ratified by Law Number 7 Year 1997 on the Legalization of UN Convention about new eradication of illegal traffic is expected to more effectively prevent and eradicate the narcotics abuse and traffic including to avoid the Republic of Indonesia from becoming the target of narcotics transit or target of illegal narcotics traffic. ${ }^{3}$

Narcotics traffic and consumption is not only done by common people but also by prisoners in prison. The reveal of drug manufacturing inside prison show that the prison is not a sterile area from illegal narcotics business. In regards to this, this research becomes significant to disclose the reason behind it.

\section{Problems}

Based on the background above, this paper will discuss law enforcement policy affecttivity in eradicating narcotics abuse among prisoners in prison as well as the impediments experienced by National Anti-Narcotics Agency in conducting the law enforcement of narcotics eradication.

\section{Research Method}

This research applied empirical juridical approach by analytical descriptive research. The research took place in National Narcotics Agency of Central Java in Semarang and Magelang Narcotics Prison. The data were analyzed based on Research and Development method (Research and Development/R\&D) and Theory of Law Enforcement Factors by Soerjono Soekanto.

\section{Discussion}

2 Fransiska Novita Eleanora, "Bahaya Penyalahgunaan Narkoba Serta Usaha Pencegahan dan Penanggulangannya", Jurnal Hukum, Vol. XXV No. 1, April 2011, Semarang: Unversitas Sultan Agung, page 440.

3 Muhammad Badri, "Program Rehabilitasi Bagi Penyalahgunaan Narkotika Dalam Prespektif UU No. 23 Tahun 2009 Tentang Narkotika", Jurnal Ilmiah Universitas Batanghari, Vol. 16 No. 3, 2016, Jambi: Universitas Batanghari, page 12 .

\section{Law Enforcement Policy in Eradicating Nar- cotics Abuse Among Prisoners}

Correctional Institutions/Facilities aims to conduct the guidance on drugs-related crime prisoners according to the provisions of Law Number 12 Year 1995 on Correctional Institution in order to realize its purposes and the fulfillment of prisoner's rights without violating basic human rights. In doing so, it changes into guidance system that initially it applies imprisonment system using retaliation concept. ${ }^{4}$

Referring to Eight Principles of Effective Correctional Intervention, there are some principles to be observed for effective result in the guidance process in Prison: first, Create a positive environment; second, Design a strong program; third, Build a high-quality staff; fourth, Understand offender's needs; fifth, Target that works; Sixth, Demonstrate good practice; seventh, Communicate with others and eighth, Evaluate progress. ${ }^{5}$ Based on the data in the field, the Correctional Institution only applies the first principle, create the positive environment. Thus, the Correctional Institution is open to other parties especially National Narcotics Agency.

Narcotics crime in Indonesia seriously increases. Law enforcement constantly encourages but this crime remains higher. One of the causes is the easy access for narcotics in markets. ${ }^{6}$ The death sentence for drugs suppliers was conducted several times but the narcotics traffic controlled within prison is hardly to eliminate.

In 2015 , the Central Java is ranked $12^{\text {th }}$ from 33 provinces in Indonesia with the number of offenders around $1.595^{7}$ that involved in nar-

4 Yusri, Et.all, "Narapidana Narkoba dan Narapidana Yang Lain di LP (Studi Kasus di LP Klas IIA Banda Aceh), Jurnal Ilmu Hukum, Vol. 3 No. 3, August 2015, Banda Aceh: Post Graduate Universitas Syah Kuala, page 74.

5 Rakei Yunardhani, "Effektifitas Lembaga Pemasyarakatan di Indonesia", Jurnal Ilmiah Kajian ilmu Sosial dan Budaya, Vol. 15 No. 2, 2013, Lampung: Faculty of Social and Political Science Universitas Lampung, page 144.

6 Herdiyan Saputra, Et.all, "Analisis Kriminologis Penyalahgunaan Narkotika dan Upaya Penanggulangannya", Jurnal Poenale, Vol. 2 No. 4, 2015, Lampung: Faculty of Law Universitas Lampung, page 6.

7 Jurnal Data Pencegahan dan Pemberantasan Pengayalahgunaan dan Peredaran Gelap Narkoba (P4GN) BNN Year 2015 Edition 2016. 
cotics cases, psychotropic, and other addictive drugs. It indicates that the rank of Central Java in this case has the second lowest in Java for the number of drug related suspects while the lowest rank is DIY (Special Region of Yogyakarta).

Based on National Narcotics Agency, it is known that the number of detainees and narcotics and illegal drugs prisoners in Central Java until December 2015 was around 1.675 suppliers and 703 users. Narcotics can be still consumed in Prison. It is proven when tools for consuming drugs were found when the raids were held.

Director General of Correction Ministry of Justice and Human Right states that there are some ways to smuggle drugs and other dangerous goods, those are: ${ }^{8}$ First, Visitation. It involves prisoner's family, friends, attorney, and churchman that serves religion value to the prisoners). Second, the staff of Correctional Institution. There are staffs who can be bribed by prisoners to give drug and others. Usually, they still has a relation with the prisoners either inmate's friend or family. Third, Food, prisoners often receive food delivery from family or someone into which the drugs can be smuggled. Fourth, Mini market inside jail providing prisoners' daily needs. Fifth, Through official visit, such as the churchman, priest or others. Sixth, assimilation prisoners who are usually used to smuggle the drugs. Seventh, prisoners who meet in court. Usually the inmate gives the drugs when he meets prisoners in the court. Seventh, incidental visitation, such as on the religion celebration day or the celebration of Independence Day.

Smuggling can also be done by inserting drugs into food, beverages, clothing, toothpaste, and other goods, throwing narcotics from the prisoners' walls, hiding narcotics inside the shirt pockets. ${ }^{9}$

8 Redaksi in Nasional, September $11^{\text {th }}$ 2016, Dirjen PAS Ungkap Sejumlah modus Penyelundupan Narkoba di Lapas, tersedia di: http://sinarkeadilan.com/2016/06/ 18/dirjen-pas-ungkap-sejumlah-modus-penyeludupannarkoba-lapas/, accessed on December $12^{\text {th }} 2016$.

$9 \quad$ Ni Putu Noni Suharyanti, "Modus Penyelundupan Narkotika dan Upaya Penanggulangannya di LP Klas IIA Denpasar, Jurnal Magister Hukum Udayana, Vol. 4 No. 1, May
The effort of National Narcotics Agency to cut down the traffic and users of narcotics in Prison is conducted by holding the raids at any time information about transaction is received. National Narcotics Agency raid is equipped with devices that can track the transaction of suspected prisons. It is expected to cut the chain of narcotics traffic to prisoners, so that the prisoners can be easily guided and directed to not involve in the narcotics abuse anymore. It is realized through rehabilitation staff including National Narcotics Agency, Prison Staffs, and public figure. The guidance focus is preferred to those who categorized relapse.

The criminal justice system in Indonesia is system that integrates sub-system of law enforcement. The sub-system starts from investigation to correctional process. Somehow, the correctional process is often ignored by many parties. The sub-system of correctional institution has a hard and very specific task compared to other sub-systems since this institution shall implement the purpose of imprisonment imposed by the sub-system of court: Correcting the personality of prisoners; Create deterrent effect; ensure prisoners to be incapable of doing other crimes, i.e. irreparable ones. ${ }^{10}$

Today, the number of prisoners in Indonesia is around 179.611 in 470 Prisons. This number placed Indonesia became the top 10 rank in the world, and $2^{\text {nd }}$ rank in ASEAN by ratio of prisoners in Prison is $149,2 \%$, with the number of employee in the Prison is around 31 thousands personnels.

The prisoner's explosion number is generally caused by the narcotics prisoners, both as a supplier and user. Based on that description, it requires all parties concern to participate in Treatment of offenders which is not only handled by correctional institution but also other sub-systems of law enforcement.

National Narcotics Agency is the institution authorized by state to arrange and implement the national policy regarding the preven-

2015, Denpasar: Faculty of Law Universitas Udayana, page 115.

10 Tolib Setiady, 2010, Pokok-Pokok Hukum Penitensier, Bandung: Alfabeta, page 31. 
tion and eradication of abuse and illegal traffic of Narcotics and Narcotics Precursor (President Decree Number 83 Year 2007). In performing the tasks, this Agency cooperates with other law enforcement one of which is correctional institution. This cooperation network is significant to handle the increasing traffic of drugs actually controlled inside prison. It reveals that although the National Narcotics Agency has modern technology to prevent or law enforcement to prisoners, the cooperation with the other law enforcement is still needed.

The relation of National Narcotics Agency with Correctional institutions need improvement despite the good intention since what socalled domino effects still occurs. For instance, incident of prison of Tanjung Gusta and Krobokan Bali. It seems that National Anti-Narcotics Agency actually raises instability conditions in prison including the damage facilities. Therefore, the relation pattern between both institutions shall be improved to avoid friction in the field.

National Narcotics Agency raids in prison was conducted impromptu and quickly for best result. Yet, correctional institution staffs feel underestimated which put them in inconvenient environment. As a result, it rises a friction as well as hindrances for law enforcement to narcotics eradication inside prison.

The impediment experienced by National Narcotics Agency (BNN) in conducting Narcotics Abuse Law Enforcement among Prisoners

From the prisoners' side, deterrent effect is not effectively experienced by the prisoners. They still cling to drugs either as suppliers or users.

The ineffectiveness of guidance in prison occurs due to the ratio gap between human resources of guidance staff and the number of prisoners. Those who are drugs addicts for long time require personal motivation guidance intensively rather than collective guidance.

The high number of prisoners enable frequent interaction among suppliers, users and other prisoners by less supervision of the Institution officials. Consequently, exprisoners en- gage more interaction among users or suppliers than education that conducted by correctional institution.

Spiritual and mental guidance cannot effectively implemented either due to the limited mentors. ${ }^{11}$ Spiritual guidance is the important part for prisoners after they completed the punishment. ${ }^{12}$

From the prison side, over capacity without adequate facilities development becomes the main problem. As a result, "snow ball" effect grows to be accumulated problems.

The low income of prison's staff and low integrity create the mutualistic symbiosis between staff to prisoners. Consequently, the institution has no authority in the prisoners' view.

\section{Conclusion}

The law enforcement policy of narcotics abuse traffic among prisoners cannot be implemented effectively since shared understanding between BNN and Correctional Institution is not established. BNN claimed that the impromptu raid in prison aims to the best result yet the correctional institutional feels underestimated. It also causes prison condition instability.

The obstacles encountered by National Anti-Narcotics Agency are explained as follows. From prisoner's perspective: deterrent effect is not proven implemented; there is no adequate guidance to start a new life after releasing from jail. From the prison side: Over capacity, low human resources and the low income of the prison staff, low the integrity of prisons staff in bearing their responsibility.

\section{Suggestions}

In this research, the writer suggest integrated and synchronized cooperation be established to prevent drugs traffic inside prison. It is done to avoid misunderstanding between Cor-

11 Ari Astuti, “Pembinaan Mental Narapidana di LP Wirogunan Yogyakarta", Jurnal Zitizenship Vol. 1 No. 1, Juli 2011. Yogyakarta: Universitas Ahmad Dahlan, page 35.

12 Muhammad Riza, Et.all, "Resiliensi Pada Narapidana laki-laki di Lapas Klas 1 Madaeng", Jurnal Psikologi Kepribadian dan Sosial, Vol. 1 No. 3, 2012, Surabaya: Universitas Airlangga, page 150. 
rectional Institution Staffs and National Narcotics Agency (BNN) in Central Java. Furthermore, a mapping is needed to separate the drugs-related prisoners from non-drugs-related prisoners. By doing so, a more focused guidance for drugs prisoners can be intensively conducted.

\section{References}

Astuti, Ari. "Pembinaan Mental Narapidana di LP Wirogunan Yogyakarta", Jurnal Zitizenship Vol.1 No. 1. July 2011. Yogyakarta: Universitas Ahmad Dahlan;

Badri, Muhammad. "Program Rehabilitasi Bagi Penyalahgunaan Narkotika Dalam Prespektif UU No. 23 Year 2009 Tentang Narkotika". Jurnal Ilmiah Universitas Batanghari Vol. 16 No. 3. 2016. Jambi: Universitas Batanghari;

Eleanora, Fransiska Novita. "Bahaya Penyalahgunaan Narkoba Serta Usaha Pencegahan dan Penanggulangnnya". Jurnal Hukum. Vol. XXV No. 1. April 2011, Semarang: Universitas Sultan Agung;

Redaksi in Nasional. 11 sept 2016. Dirjen PAS Ungkap Sejumlah modus Penyelundupan Narkoba di Lapas, tersedia di: http:// sinarkeadilan.com/2016/06/18/dirjenpas-ungkap-sejumlah-modus-penyelundup an-narkoba-lapas/. Access on December $12^{\text {th }} 2016$;

Jurnal Data Pencegahan dan Pemberantasan Pengayalahgunaan dan Peredaran Gelap Narkoba (P4GN) BNN Year 2015 Edition 2016;
Noni Suharyanti, Ni Putu. "Modus Penyelundupan Narkotika dan Upaya Penanggulangannya di LP Klas IIA Denpasar. Jurnal Magister Hukum Udayana. Vol. 4 No. 1. May 2015. Denpasar: Faculty of Law Universitas Udayana;

Ricardo, Paul. "Upaya Penanggulangan Penyalahgunaan Narkoba Oleh Kepolisian (Studi Kasus Satuan Narkoba Metro Bekasi)". Jurnal Kriminologi Indonesia. Vol. 6 No. III. December 2010. Jakarta: Department of Criminology, Universitas Indonesia;

Riza, Muhammad. Et.all. "Resiliensi Pada Narapidana laki-laki di Lapas Klas 1 Madaeng", Jurnal Psikologi Kepribadian dan Sosial Vol. 1 No. 3. 2012. Surabaya: Universitas Airlangga;

Saputra, Herdiyan. Et.all. "Analisis Kriminologis Penyalahgunaan Narkotika dan Upaya Penanggulangannya”. Jurnal Poenale. Vol. 2 No. 4. 2015. Lampung: Faculty of Law Universitas Lampung;

Setiady, Tolib. 2010. Pokok-Pokok Hukum Penitensier. Bandung: Alfabeta;

Yusri. Et.all. "Narapidana Narkoba dan Narapidana Yang Lain di LP (Studi Kasus di LP Klas IIA Banda Aceh). Jurnal IImu Hukum. Vol. 3 No. 3. August 2015. Banda Aceh: Post Graduate, Universitas Syah;

Yunardhani, Rakei. "Effektifitas Lembaga Pemasyarakatan di Indonesia", Jurnal Ilmiah Kajian ilmu Sosial dan Budaya. Vol. 15 No. 2. 2013. Lampung: Faculty of Social and Political Science Universitas Lampung. 